\begin{tabular}{lc|}
\hline \hline UAD & Jurnal Psikologi Terapan dan Pendidikan \\
Vol. 2, No. 1, Mei 2020, pp. 55-60 \\
ISN 27152-2456 \\
$\begin{array}{l}\text { Universitas } \\
\text { Ahmad Dahlan }\end{array}$ \\
http://journal.uad.ac.id/index.php/Psikologi/index
\end{tabular}

\title{
Pengaruh kecerdasan emosional dan organizational citizenship behavior terhadap kinerja penyuluh agama Islam non PNS Kementerian Agama kota Yogyakarta
}

\author{
Evi Ni'Matuzzakiyaha, ${ }^{\text {* }}$ \\ aSekolah Tinggi Ilmu Kesehatan Surya Global, Yogyakarta \\ *1evi@gmail.com \\ Correspondent Author
}

\section{KATAKUNCI}

kecerdasan emosional; kinerja; organizational citizenship behavior; penyuluh agama Islam

\section{KEYWORDS}

emotional intelligence; Islamic religious extension; organizational citizenship behavior;

performance
ABSTRAK

Tugas penyuluh Agama Islam Non PNS di masyarakat semakin berat, karena pada saat ini kehidupan masyarakat mengalami perubahan pola hidup yang menonjol. Sementara minimnya honorarium yang diterima Penyuluh Agama Islam Non PNS masih di bawah Upah Minimum Regional (UMR), artinya belum sebanding dengan dedikasi dan loyalitas mereka dalam menjalankan peran dan fungsinya. Dengan denikian, dibutuhkan kecerdasan emosional untuk menguatkan komitmen dan perilaku organizational citizenship dalam menjalankan kinerja sebagai penyuluh Agama Islam. Metode pada penelitian ini menggunakan pendekatan kuantitatif. Partisipan penelitian ini berjumlah 37 orang yang melibatkan penyuluh Agama Islam Non PNS Kementerian Agama Kota Yogyakarta. Alat ukur yang digunakan adalah skala kecerdasan emosional, skala organizational citizenship behavior, dan kinerja. Teknik analisis yang digunakan untuk mengolah ketiga data yaitu analisis regresi berganda. Hasil penelitian menunjukan koefisien $F_{\text {reg }}=44,341$ dan $\mathrm{p}=0,000(\mathrm{p}<0,001)$, yang artinya ada pengaruh yang sangat signifikan antara kecerdasan emosional dan organizational citizenship behavior terhadap kinerja penyuluh Agama Islam non PNS. Selanjutnya nilai koefisien determinasi $\left(\mathrm{R}^{2}\right)$ sebesar 0,707 yang menunjukkan bahwa kecerdasan emosional dan organizational citizenship behavior secara bersama-sama memberikan sumbangan terhadap kinerja sebesar 70,7\%. Penelitian ini menyimpulkan bahwa kecerdasan emosional dan organizational citizenship behavior secara bersama-sama memiliki pengaruh dan mampu menjadi prediktor terhadap kinerja penyuluh Agama Islam non PNS.

The influence of emotional intelligence and organizational citizenship behavior on the performance of non-civil servant Islamic religious educators at the Ministry of Religion of Yogyakarta

The task of non-civil servant Islamic extension agents in the community is getting heavier, because at this time people's lives are experiencing a prominent lifestyle change. Meanwhile, the minimum honorarium received by Non PNS Islamic Religious Instructors is still below the Regional Minimum Wage (UMR), meaning that it is not yet comparable to their dedication and loyalty in carrying out their roles and functions. Thus, emotional intelligence is needed to strengthen commitment and behavior of organizational citizenship in carrying out performance as extension agents of Islam. The method in this study uses a quantitative approach. The number of participants in this study was 37 people who 
involved non-civil servant Islamic religious extension officers at the Ministry of Religion, Yogyakarta City. The measuring instruments used were emotional intelligence scale, organizational citizenship behavior scale, and performance. The analysis technique used to process the three data is multiple regression analysis. The results showed the coefficient of Freg $=44.341$ and $p=0.000$ ( $p<0.001)$, which means that there was a very significant influence between emotional intelligence and organizational citizenship behavior on the performance of non-civil servant Islamic religious extension workers. Furthermore, the coefficient of determination $\left(R^{2}\right)$ is 0.707 which indicates that emotional intelligence and organizational citizenship behavior together contribute to performance by $70.7 \%$. This study concludes that emotional intelligence and organizational citizenship behavior together have an influence and can be a predictor of the performance of non-civil servant Islamic religious extension workers.

This is an open-access article under the CC-BY-SA license.

\section{Pendahuluan}

Tuntutan kinerja dan tanggung jawab Penyuluh Agama Islam di Indoneisa adalah untuk menyampaikan misi keagamaan dan pembangunan. Penyuluh juga berperan sebagai panutan, media advokasi, tempat bertanya, mengadu, dan menyelesaikan berbagai masalah yang dihadapi oleh umat Islam. Seiring dengan laju perkembangan ilmu pengetahuan dan teknologi, maka tantangan tugas, peran dan fungsi penyuluh di masyarakat semakin berat, karena pada kenyataannya kehidupan masyarakat mengalami perubahan pola hidup yang menonjol. Sementara minimnya honorarium yang diterimakan kepada Penyuluh Agama Islam Non PNS masih dibawah Upah Minimum Regional (UMR), yang menunjukan bahwa belum sebanding dengan dedikasi dan loyalitas penyuluh dalam menjalankan peran dan fungsinya.

Berdasarkan pada realita yang ada, secara otomatis Penyuluh Agama Islam Non PNS dituntut untuk memiliki kemampuan mengontrol emosi diri, dan hal tersebut menjadi bagian yang sangat penting supaya tidak terbawa aliran dan elemen negatif (Yahaya, Boon, Hashim, \& Lee, 2012). Kemampuan mengontrol emosi diri menjadi salah satu aspek dari kecerdasan emosional. Artinya, kecerdasan emosional yang tinggi akan membantu menjaga harmonisasi dan kenyamanan psikologis penyuluh (Yahaya et. al, 2012).

Patton (1998) menjelaskan bahwa seseorang yang memiliki kecerdasan emosi akan mampu menghadapi tantangan. Begitupula bahwa dengan kecerdasan emosi yang dimiliki dapat menjadikan seseorang bersikap penuh tanggung jawab, produktif, optimis dalam menghadapi, dan menyelesaikan masalah. semua keterampilan tersebut sangat dibutuhkan di dalam lingkungan kerja. Sementara Shapiro (1997) menyatakan bahwa kecerdasan emosional dapat membuat seseorang menjadi bersemangat tinggi dalam bekerja, disukai dalam pergaulan, bertanggung jawab, peduli pada orang lain dan dapat meningkatkan produktivitas.

Selain kecerdasan emosional, perilaku kooperatif dan saling membantu di antara sesama Penyuluh Agama Islam Non PNS di luar persyaratan formal sangat penting bagi berfungsinya suatu organisasi yang menaungi mereka. Perilaku tambahan di luar deskripsi pekerjaan dalam organisasi disebut sebagai organizational citizenship behavior (Kartz, dalam Sumiyarsih, Mujiasih, Ariati, 2012). Organizational citizenship behavior adalah perilaku yang dapat membantu keefektifan organisasi karena memiliki kapasitas sosial untuk bekerja sama 
dengan orang lain dan memiliki karakter yang kuat untuk mempertahankan kelompok kerjanya (Suzana, 2017)

Organizational citizenship behavior memiliki peran dalam perspektif keefektifan penilaian kinerja dalam pengembangan organisasi (Suzana, 2017). Organizational citizenship behavior sangat penting dalam keberlangsungan hidup organisasi (Gibson, Ivancevich, Konopaske, Rosales, Quiñones, \& Romero 2011). Robin dan Judge (2007) menyatakan bahwa elemen penting dalam organisasi adalah perilaku di luar aturan formal organisasi (extra role) dibandingkan dengan melakukan pekerjaan sesuai dengan tugas yang ada dalam deskripsi kerja (in role). Oleh karena itu, hal tersebut secara langsung dan tidak langsung akan mempengaruhi kinerja Penyuluh Agama Islam Non PNS.

Tujuan dari penelitian ini adalah untuk mengetahui sejauh mana pengaruh kecerdasan emosional dan Organizational Citizenship Behavior terhadap kinerja Penyuluh Agama Islam Non PNS di Kementerian Agama Kota Yogyakarta. Kontribusi yang diharapkan dengan melakukan penelitian ini adalah agar menjadi rekomendasi bagi kementrian Agama kota Yogyakarta dalam peningkatan Organizational Citizenship Behavior penyuluh agama yang akan berdampak pada peningkatan kinerja individu ataupun organisasi.

\section{Metode}

Partisipan pada penelitian ini adalah para penyuluh Agama Islam Non-PNS yang bertugas di Kantor Urusan Agama di 14 kecamatan yang ada di wilayah kota Yogyakarta. Adapun alat ukur yang digunakan adalah skala kecerdasan emosional, skala organizational citizenship behavior, dan skala kinerja. Sebelum dilakukan penelitian, maka peneliti melakukan tryout alat ukur kepada 35 orang di kota Yogyakarta.

Adapun koefisien reliabilitas skala kecerdasan emosional adalah sebesar 0,975. Koefisien reliabilitas skala organizational citizenship behavior adalah sebesar 0,904. Selanjutnya koefisien reliabilitas skala kinerja adalah sebesar 0,966. Berdasarkan perolehan koefisien reliabilitas dari ketiga ala ukur tersebut menunjukan bahwa koefisien reliabilitas lebih besar dari kriteria standar minimal nilai reliabilitas yaitu 0,600. Dengan demikian, dapat dikatakan bahwa instrumen/ alat ukur penelitian sudah reliabel. Setelah melakukan pengujian alat ukur, selanjutnya peneliti melakukan penelitian kepada 37 orang Penyuluh Agama Islam Non PNS di wilayah kerja Kementerian Agama kota Yogyakrta untuk mengisi tiga skala penelitian yang telah disiapkan.

Data yang diperoleh selanjutnya dianalisis dengan menggunakan teknik analisis regresi berganda. Pertimbangan menggunakan teknik analisis regresi berganda karena penelitian ini mengungkap dua prediktor dengan satu kriterium.

\section{Hasil}

Sebelum dilakukan pengujian hipotesis, peneliti melakukan uji asumsi atau uji prasyarat terlebih dahulu. Adapun tujuannya adalah untuk mengetahui apakah data yang diperoleh memenuhi syarat untuk dianalisis guna menguji hipotesis penelitian. Uji asumsi yang dilakukan meliputi uji normalitas dan uji multikolonieritas.

Hasil uji normalitas menunjukkan nilai asymp. sig.(2-tailed) adalah 0,985, berarti dari nilai asymp. sig.(2-tailed) > 0,05 (alpha), maka nilai residual terstandarisasi dikatakan menyebar secara normal (Suliyanto, 2005). Selanjutnya hasil analisis menunjukkan nilai tolerance untuk variabel kecerdasan emosional dan organizational citizenship behavior sebesar 0,585 lebih besar dari 0,10 dan nilai VIF (Variance Inflation Factor) sebesar 1,708 kurang dari 10, sehingga dikatakan data yang ada pada kedua variabel bebas tersebut tidak terjadi multikolinear.

Perhitungan hasil analisis regresi diperoleh nilai $F_{\text {reg }}=44,341$ dan $p=0,000(p<0,001)$. Artinya, ada pengaruh yang sangat signifikan antara kecerdasan emosional dan organizational citizenship behaviour secara bersama-sama terhadap kinerja penyuluh Agama 
Islam non-PNS (hipotesa diterima). Dengan demikian, dapat dikatakan bahwa kecerdasan emosional dan organizational citizenship behaviour secara bersama-sama mampu menjadi prediktor kinerja penyuluh Agama Islam non-PNS.

Nilai koefisien determinasi $\left(\mathrm{R}^{2}\right)$ sebesar 0,707 menunjukkan bahwa kecerdasan emosional dan organizational citizenship behavior secara bersama-sama memberikan sumbangan (daya prediksi) terhadap kinerja sebesar 70,7\%. Sementara sisa sebesar 29,3\% merupakan sumbangan dari faktor lain ataupun diasumsikan adanya kesalahan-kesalan lain (error sampling dan non sampling). Berikut ringkasan dari data perolehan berdasarkan hasil analisis data dengan teknik analisis regresi ganda (tabel 1).

Tabel 1.

Hasil Uji Regresi Berganda

\begin{tabular}{llll}
\hline $\boldsymbol{R}$ & $\boldsymbol{F}$ & $\boldsymbol{R}^{\mathbf{2}}$ & Sig. \\
\hline 0,850 & 44,341 & 0,707 & 0,000 \\
\hline
\end{tabular}

Hasil analisis model dari kedua variabel bebas terhadap variabel tergantung menunjukan persamaan regresi yang diperoleh dari hasil perhitungan analisis adalah $Y=(-$ $0,805) \mathrm{a}+(0,446) \mathrm{X}_{1}+(0,317) \mathrm{X}_{2}$, seperti yang tampak pada tabel 2 berikut.

Tabel 2.

Hasil Uji Regresi Berganda

\begin{tabular}{lllll}
\hline Model & $\boldsymbol{B}$ & Beta & $\boldsymbol{t}$ & Sig. \\
\hline Konstanta & $-0,805$ & & $-0,061$ & 0,952 \\
Kecerdasan Emosional & 0,446 & 0,561 & 4,751 & $0,000^{*}$ \\
Organizational Citizenship Behavior & 0,317 & 0,373 & 3,161 & 0,003 \\
\hline
\end{tabular}

Berdasarkan persamaan garis regresi pada tabel 2, dapat dijelaskan sebagai berikut:

1. Koefisien konstanta kecerdasan emosional bernilai positif, yaitu 0,446, artinya setiap kenaikan nilai kecerdasan emosional 1 poin, akan meningkatkan variabel kinerja 0,446 dengan asumsi variabel lain bernilai tetap. Penyuluh Agama Islam Non-PNS yang memiliki kecerdasan emosional tinggi diprediksi akan memiliki kinerja yang baik dibandingkan dengan mereka yang kurang dalam kemampuan kecerdasan emosional.

2. Koefisien konstanta organizational citizenship behavior bernilai positif, yaitu 0,317, artinya setiap kenaikan nilai organizational citizenship behavior 1 poin, akan meningkatkan variabel kinerja 0,317 dengan asumsi variabel lain bernilai tetap. Penyuluh Agama Islam Non-PNS yang memiliki organizational citizenship behavior yang tinggi diprediksi akan memiliki kinerja yang baik dibandingkan dengan mereka yang kurang dalam organizational citizenship behavior.

Adapun kategorisasi partisipan berdasarkan skor kecerdasan emosional, dapat diidentifikasi bahwa secara umum penyuluh Agama Islam Non-PNS memiliki kecerdasan emosional yang berada pada kategori sedang, yaitu sebanyak 67,6\%. Sementara hanya sebagian kecil dari penyuluh Agama Islam Non-PNS memiliki kecerdasan emosi yang tergolong tinggi yaitu sebesar 18,9\%, begitupula yang tergolong rendah yaitu sebesar 13,5\%. Kategorisasi kecerdasan emosional dapat dilihat pada tabel 3.

Tabel 3.

Kategorisasi Kecerdasan Emosional Partisipan Penelitian

\begin{tabular}{llll}
\hline Skor Interval & Klasifikasi & $\boldsymbol{N}$ & Prosentase \\
\hline $\mathrm{X}>194,52$ & Tinggi & 7 & 18,9 \\
$194,52<\mathrm{X}<161,16$ & Sedang & 25 & 67,6 \\
$\mathrm{X}<161,16$ & Rendah & 5 & 13,5 \\
\hline
\end{tabular}


Seiring dengan kecerdasan emosional, skor organizational citizenship behavior partisipan juga didominansi pada ketegori sedang, yaitu sebanyak 73\% penyuluh Agama Islam Non-PNS memiliki organizational citizenship behavior rata-rata pada umumnya. Sementara sebagian kecil dari penyuluh Agama Islam Non-PNS memiliki organizational citizenship behavior dalam kategori tinggi, yaitu sebesar 18,9\%, dan kategori rendah yaitu sebesar $8,1 \%$. Kategorisasi organizational citizenship behavior dapat dilihat pada tabel $4 \mathrm{di}$ bawah ini.

Tabel 4.

Kategorisasi Organizational Citizenship Behavior Subjek Penelitian

\begin{tabular}{llll}
\hline Skor Interval & Klasifikasi & $\boldsymbol{N}$ & Prosentase \\
\hline $\mathrm{X}>157,08$ & Tinggi & 7 & 18,9 \\
$157,08<\mathrm{X}<125,78$ & Sedang & 27 & 73 \\
$\mathrm{X}<125,78$ & Rendah & 3 & 8,1 \\
\hline
\end{tabular}

Berbanding lurus dengan kecerdasan emosional dan organizational citizenship behavior, hanya sebagian kecil dari penyuluh Agama Islam Non-PNS memiliki kinerja yang tinggi yaitu sebesar $13,5 \%$, begitupula kinerja yang rendah yaitu sebesar $16,2 \%$. Sedangkan selebihnya yaitu sebanyak 70,3\% penyuluh Agama Islam Non-PNS memiliki kinerja yang relatif cukup bagus. Kategorisasi kinerja dapat dilihat pada tabel 5 di bawah ini.

Tabel 5.

Kategorisasi Kinerja Partisipan Penelitian

\begin{tabular}{llll}
\hline Skor Interval & Klasifikasi & $\boldsymbol{N}$ & Prosentase \\
\hline $\mathrm{X}>136,66$ & Tinggi & 5 & 13,5 \\
$136,66<\mathrm{X}<110,1$ & Sedang & 26 & 70,3 \\
$\mathrm{X}<110,1$ & Rendah & 6 & 16,2 \\
\hline
\end{tabular}

\section{Pembahasan}

Kecerdasan emosional dan organizational citizenship behavior secara bersama-sama memberikan sumbangan (daya prediksi) terhadap kinerja sebesar 70,7\%. Melalui kecerdasan emosional yang tinggi akan membantu menjaga harmonisasi dan kenyamanan psikologis (Yahaya et.al, 2012) dan organizational citizenship behavior dapat membantu keefektifan organisasi karena memiliki kapasitas sosial untuk menguatkan kerja sama dan memberi warna karakter yang kuat untuk mempertahankan kelompok kerja suatu organisasi (Suzana, 2017).

Ada dua istilah kecakapan dalam mengenal kecerdasan emosional, yaitu kecakapan intrapribadi dan antarpribadi. Kecakapan intrapribadi adalah kemampuan dalam diri yang bersifat korelatif dan terarah untuk membentuk suatu model diri sendiri serta kemampuan untuk menggunakan model tersebut sebagai alat yang dipergunakan dalam mengarungi kehidupan dengan lebih efektif, sedangkan kecerdasan antar pribadi adalah kemampuan untuk memahami orang lain dalam hal pemahaman terhadap apa yang memotivasi mereka, bagaimana mereka bekerjasama dengan sesamanya, dan mampu membedakan serta menanggapi suasana hati, temperamen, motivasi, dan hasrat orang lain secara tepat (Gardner, dalam Holt \& Jones, 2005).

Menurut Sumiyarsih, Mujiasih, dan Ariati (2012) dalam penelitian mereka menemukan bahwa ada hubungan yang signifikan antara organizational citizenship behavior dengan kecerdasan emosional. Tanda positif pada koefisien korelasi menunjukkan arah hubungan positif, yang berarti bahwa semakin tinggi kecerdasan emosional maka semakin tinggi organizational citizenship behavior. Organizational citizenship behavior memiliki peran dalam perspektif keefektifan penilaian kinerja karyawan, terutama dalam pengembangan 
perusahaan, bahwa semakin detail sebuah penilaian kinerja karyawan dalam suatu perusahaan, maka semakin terkaitlah persoalan sebagai salahsatu alternatif penilaian kinerja karyawan pada perusahaan dengan sistem penilaian yang bersifat tidak formil untuk melibatkan karyawan dalam keputusan perusahaan dengan memberikan kewajiban secara personal, karena dengan meningkatnya professionalitas sumber daya manusia, maka tujuan perusahaan akan dapat tercapai secara efektif, efisien, dan produktif (Suzana, 2017).

Jika perusahaan atau organisasi ingin meningkatkan organizational citizenship behavior karyawan atau anggota, maka perusahaan atau organisasi perlu memerhatikan faktor-faktor yang memengaruhi organizational citizenship behavior dan implikasinya terhadap perusahaan atau organisasi (Kusumajati, 2014).

Adapun keterbatasan dalam penelitian ini adalah jumlah subjek yang sedikit, meskipun hasil dari penelitian menunjukkan hasil yang signikan, akan tetapi pengukuran berdasarkan self-reports dapat berpotensi pada biasnya respon subjek.

\section{Simpulan}

Penelitian ini menyimpulkan bahwa besarnya peran dan fungsi penyuluh Agama Islam Non PNS di masyarakat menuntut mereka untuk memiliki kinerja yang tinggi dalam rangka membantu tercapainya tujuan organisasi. Kecerdasan emosi dan organizational citizenship behavior merupakan faktor yang memberikan pengaruh besar terhadap peningkatan kinerja penyuluh dalam meningkatkan efektifitas dan pengembangan organisasi, yang pada akhirnya memengaruhi kinerja mereka sebagai penyuluh Agama Islam secara menyeluruh.

\section{DAFTAR PUSTAKA}

Gibson, J. L., Ivancevich, J. M., Donnelly, J. H., Konopaske, R., Rosales, M. E. T., Quiñones, A. D., ... \& Romero, H. A. G. (2011). Las organizaciones: comportamiento, estructura, procesos. México: McGraw-hill.

Holt, S., \& Jones, S. (2005). Emotional intelligence and organizational performance: Implications for performance consultants and educators. Performance Improvement, 44(10), 15-21.

Kusumajati, D. A. (2014). Organizational citizenship behavior (OCB) karyawan pada perusahaan. Humaniora, 5(1), 62-70.

Patton, P. (1998). Emotional intelligence in the workplace. Jakarta. Pustaka Delaprata.

Rangkuti, F. (1997). Riset pemasaran. Gramedia Pustaka Utama.

Robbins, S. P., \& Judge, T. A. (2007). Organizational behavior. New Jersey: Person Education. Inc.

Shapiro, L. E. (1997). How to raise a child with a high EQ: A parent's guide to emotional intelligence. HarperCollins.

Sumiyarsih, W., Mujiasih, E., \& Ariati, J. (2012). Hubungan antara kecerdasan emosional dengan organizational citizenship behavior (OCB) pada karyawan CV. Aneka Ilmu Semarang. Jurnal Psikologi Undip, 11(1).

Suzana, A. (2017). Pengaruh organizational citizenship behavior (ocb) terhadap kinerja karyawan (studi di: Pt. Taspen (persero) kantor cabang cirebon). LOGIKA Jurnal Ilmiah Lemlit Unswagati Cirebon, 19(1), 42-50.

Yahaya, N., Boon, Y., Hashim, S., \& Goh, M. L. (2012). The impact of emotional intelligence element on academic achievement. Archives Des Sciences, 65(4), 2-17. 